九州大学学術情報リポジトリ

Kyushu University Institutional Repository

Effects of Dietary Tricalcium Phosphate on the Growth and Mineral Availability in Japanese Flounder

Hossain, M. Amzad

Fishery Research Laboratory, Faculty of Agriculture, Kyushu University

Furuichi, Masayuki

Fishery Research Laboratory, Faculty of Agriculture, Kyushu University

https://doi.org/10.5109/24328

出版情報：九州大学大学院農学研究院紀要. 44 (3/4)，pp.273-277，2000-02. Kyushu University バージョン：

権利関係 : 
J. Fac. Agr., Kyushu Lniv., $44(3 \cdot 4), 273-277$ (2000)

\title{
Effects of Dietary Tricalcium Phosphate on the Growth and Mineral Availability in Japanese Flounder*
}

\author{
M. Amzad Hossain and Masayuki Furuichi \\ Fishery Research Laboratory, Faculty of Agriculture, Kyushu University, \\ Tsuyazaki, Fukuoka 811-3304, Japan \\ (Received October 20, 1999 and accepted November 5, 1999)
}

\begin{abstract}
A 10-week fecding trial was conducted to investigate the effects of dietary tricalcium phosphate (TCP) on growth and mineral availability in juvenile Japanese flounder (Paralichthys olinaceus). A $0.25 \%$ Ca supplement from Ca-lactate 10 the diet (diet 2) significantly increased the growth of fish compared to the basal diet 1 without a Ca supplement. However, a dietary supplement of $2.5 \% \mathrm{Ca}$ from TCP (diet 3) did not improve the growth and decreased $\mathrm{Zn}$ and $\mathrm{Mn}$ contents of bone when compared to the basal diel. 1 . A $0.25 \% \mathrm{Ca}$ supplement from Ca-lactate to the dict (dict 1 ), in addition to the $2.5 \%$ Ca supplement. from TCP: also could not improve the growth and $\mathrm{Zn}$ and Mn contents of bone. A Zn supplement to the diet (diet 5), in addition to the $2.5 \%$ Ca supplement from TCP, increased the $\mathrm{Zn}$ content of bone but did not improve the growth. The present study suggest,s that dietary TCP introduces decreased growth and low availability of $7 \mathrm{n}$ and $\mathrm{Mn}$ in Japartese flounder and that easily digestible Ca supplementation to the TCP-riched diet alone can not improve the growth and mineral availability. In a TCP riched diet (fish meal diet, for example), both easily digestible $\mathrm{Ca}$ and higher amounts of $\mathrm{Zn}$ and $\mathrm{Mn}$ supplements may be necessary for obtaining improved growth and rnineral availability in juvenile Japanese flounder.
\end{abstract}

\section{INTRODUCTION}

It has been reported that tricalcium phosphate (TCP) interacts with minerals in a diet. Low availability of $\mathrm{Zn}$ in the presence of TCP has been reported for some fishes (Richardson et al., 1985; Satoh el al., 1987a,b). In the previous study, we observed that a high level of dietary TCP decreased the weight gain and reduced some trace elements in bone of Japanese flounder (Hossair and Furuichi, 2000). However it was not clear from the previous study that how dietary TOP decreases the growth in this species. The poor growth might, be attributed to a deficiency of $\mathrm{Ca}$, because Ca from TCP was less available in some fish. Another possible reason for the poor growth might be due to the less availability of $\mathrm{Zn}$ in the presence of TCP. In the present study we have investigated the possiblc causes of poor growth introduced by TCP in Japanese flounder.

\section{MATERIALS AND METHODS}

\section{Experimental Diets}

A basal diet (diet 1) was formulated with $45 \%$ vitamin-free casein and $10 \%$ squid meal as dietary protein sources (Table 1). A Ca-free mineral mixture was supplied to the

\footnotetext{
* Contribution from Fishery Research Laboratory, Kyushu University (No. 249).
} 
Table 1. Composition of the basal diet for tapanese flounder

\begin{tabular}{lc}
\hline Ingredicnt & $(\mathrm{d} /)$ \\
\hline Casein & 45 \\
Squid meal & 10 \\
$\alpha-$ Starch & 5 \\
Dextrin & 10 \\
Pollack liver oil & 10 \\
Vitamin mix*1 & 3 \\
Mincral mix*2 & 5 \\
Feeding stimulants*:3 & 2 \\
Guar gum & 3 \\
a-Cellulose & 7 \\
\hline
\end{tabular}

*l Vitarnin mixlure: Halver (1957).

*2 Ca-free mineral mixture (in $100 \mathrm{~g}$ mixlure): major elements in g: $\mathrm{KCl} 7.68 ; \mathrm{MgSO}_{+} \cdot 5 \mathrm{H}_{2} \mathrm{O} 8.16 ; \mathrm{NaH}_{2} \mathrm{PO}_{1} \cdot 2 \mathrm{H}_{3} \mathrm{O}$ 68.52; Fe-citrate 2.40 ; cellulose 12.69 ; minor elements in mg: $\mathrm{AlCl}_{3} \cdot 6 \mathrm{H}_{3} \mathrm{O} 90.0 ; 7_{21 S O} \cdot 7 \mathrm{H}_{2} \mathrm{O} 264.0 ; \mathrm{MnSO}_{4} \cdot 5 \mathrm{H}_{2} \mathrm{O}$ 175.3; $\mathrm{CuCl} 15.7$; KI 3.7; $\mathrm{CoCl}_{2}-6 \mathrm{H}_{3} \mathrm{O} 1.3$.

*: Feeding stimulants (Takaoka et al., 1995): alanine 6.50; aspartate $\cdot \mathrm{Na} 1.05$; betaine 33.95 ; glycine 16.45 ; serine 1.20 ; and cellulose $40.85(\%)$.

Table 2. Proximate and mineral composition of the experimental dicts for Japanese flounder

\begin{tabular}{|c|c|c|c|c|c|}
\hline Diet no. & 1 & 2 & 3 & 4 & 5 \\
\hline $\mathrm{Ca}$ from $\mathrm{Ca}$-lactate $(\%)$ & 0 & 0.25 & 0 & 0.25 & 0 \\
\hline Ca from TCP $(\%)$ & 0 & 0 & 2.5 & 2.5 & 2.5 \\
\hline $\mathrm{Zn}(\mathrm{mg} / \mathrm{kg})$ & 30 & 30 & 30 & 30 & 80 \\
\hline \multicolumn{6}{|c|}{ Proximate composition (\% dm)* } \\
\hline Moisture & 16.9 & 18.0 & 17.9 & 18.0 & 17.5 \\
\hline Crude protein & 49.5 & 49.2 & 49.7 & 49.0 & 50.0 \\
\hline Crude lipid & 10.5 & 10.6 & 10.2 & 103 & 10.0 \\
\hline Crude ash & 4.5 & 4.6 & 9.6 & 10.5 & 10.1 \\
\hline \multicolumn{6}{|c|}{ Mineral composition (dm) } \\
\hline $\mathrm{Ca}(\%)$ & 0.02 & 0.28 & 2.55 & 2.78 & 2.52 \\
\hline$P(\%)$ & 0.98 & 1.00 & 0.96 & 1.00 & 0.91 \\
\hline$K(\%)$ & 0.20 & 0.20 & 0.20 & 0.21 & 0.23 \\
\hline $\mathrm{Mg}(\mu \mathrm{g} / \mathrm{g})$ & 380 & 370 & 370 & 360 & 370 \\
\hline $\mathrm{Fe}(\mu \mathrm{g} / \mathrm{g})$ & 270 & 270 & 280 & 280 & 270 \\
\hline $\ln (\mu \mathrm{g} / \mathrm{g})$ & 49 & 47 & 49 & 50 & 95 \\
\hline $\operatorname{Mn}(\mu \mathrm{g} / g)$ & 25 & 24 & 23 & 25 & 26 \\
\hline $\mathrm{Cu}(\mu \mathrm{g} / \mathrm{g})$ & 12 & 11 & 12 & 13 & 11 \\
\hline
\end{tabular}

* dm, dry matter basis. 
basal diet to provide $30 \mathrm{mg} \mathrm{Zn} / \mathrm{kg}$ diet in addition to other minerals. Diet 2 was obtained by supplying $0.25 \%$ Ca from Ca-lactate to the basal diet 1 . Diets $3-5$ were supplied with $2.5 \%$ Ca from tricalcium phosphate (TCP). In addition to TCP supplementation, $0.25 \%$ Ca from Ca-lactate and $80 \mathrm{mg} / \mathrm{kg} \mathrm{Zn}$ from $\mathrm{Zn}$-sulfate were supplied to diets 4 and 5 , respectively. The procedure for diet preparation was the same as that reported previously (Hossain and l'uruichi, 1999). The proximate and mineral compositions of the experimental diets are shown in Table 2.

\section{Fish and Feeding Trial}

Juvenile Japanese flounder were obtained from Fukuoka Prefectural High School of Fisheries and acclimated to the laboratory conditions at Fukuoka Mariculture Corporation for 2 weeks. The fish were fed the experimental diet 2 during acclimatization. The feeding trial was carried out in $100 \ell$ round polycarbonate tanks with a running water system with filtered sea water at a flow rate of $2-3 \mathrm{k} / \mathrm{min}$. Wal er temperature during 1 he feeding trial was $27.0 \pm 1.4^{\circ} \mathrm{C}$. At the beginning of the feeding trial, the fish (average body weight $0.38 \mathrm{~g}$ ) were weighed individually and distributed to 5 rearing tanks ( 35 fish/lank). Differences in the mean body weight, of fish among the tanks and standard deviation within a tank were kept minimum. The fish were fed the experimental diets to satiation twice a day for 10 weeks. Biweekly wcighing and other rearing methods were the same as those described previously (Hossain and Furuichi, 1999).

\section{Sample Collection and Analysis}

The fish werc anaesthetized with over exposure to MS-222 after 18-24 h starving at the termination of rearing experiment. Body weight and body length were recorded. The sample collection and chemical analyses were done by the methods mentioned previously (Hossain and Furuichi, 1999). The data were analyzed for significance using Fisher's Protected Least Significant Difference (Fisher's PJSD), $P<0.05$ ).

\section{RESLLTS AND IDISCUSSION}

$\Lambda 0.25 \%$ Ca supplement through Ca-lactate to the diet (diet 2) significantly increased the growth and feed efficiency of fish compared to the basal diet without a Ca supplement (Table 3). These results are further confirmation of our previous study where poor growth was observed in Japanese flounder when Ca was not supplemented to the diet, which indicated that Japanese flounder could not absorb adcquate Ca from sea water to support the growth (Hossain and Furuichi, 2000a). A high level of TCP supplement $(2.5 \% \mathrm{Ca})$ to the dict (diet 3) could not improved the growth of fish compared to the basal diet, indicating that Ca from TCP was not possibly available to Japanese flounder. Furthermore, remarkably low bone $\mathrm{Zn}$ content was observed in fish fed the diet 3 (Table 4). Dietary TCP in diet 3 also tended to decrease the Mn content of bone. These indicate that dictary TCP decreased the availability of $\mathrm{Zn}$ and $\mathrm{Mn}$ in Japanese flounder. A growth depression duc to the dietary TCP also has been reported for some other species such as tiger puffer and red sea bream (Hossain and Furuichi, 1998, 2000b). Low bioavailability of $\mathrm{Zn}$ due to the dietary TCP has been reported for some fresh water fishes (Hardy and Shearer, 1985; Satoh et al., 1987a, b; Gatlin and Phillips, 1989). A minimum dietary Zn 
requirement of channel catfish and rainbow trout was quite higher in practical diets containing fish meal than purified or semi-purified diet due to the presence of TCP in fish meal (Gatlin and Wilson, 1984; Satoh et al, 1987a). A 0.25\% Ca supplement to the diet through Ca-lactate, in addition to TCP (diet 4), could not improve the growth and bone $\mathrm{Zn}$ and Mn contents. A higher amount of Zn supplementation to the diet (diet 5), in addition to TCP, improved the $\mathrm{Zn}$ content in bone, however, could not increase the growth. These results indicate that in a TCP-riched diet, either easily digestible Ca or Zn supplement can not improve the growth of Japanese flounder. The combined addition of

Table 3. Growth performances of Japancse flounder fed the experimental diets

\begin{tabular}{|c|c|c|c|c|c|}
\hline Diet no. & 1 & 2 & 3 & 4 & $\overline{5}$ \\
\hline Ca from Ca-lactate $(\%)$ & () & 0.25 & 0 & 0.25 & 0 \\
\hline Ca from TCP $(\%)$ & 0 & 0 & 2.5 & 2.5 & 2.5 \\
\hline $\mathrm{Zn}(\mathrm{mg} / \mathrm{kg})$ & 30 & 30 & 30 & 30 & 80 \\
\hline \multicolumn{6}{|l|}{ Av. body wt. (g) } \\
\hline Initial & $0.38 \pm 0.06$ & $0.38 \pm 0.06$ & $0.38 \pm 0.07$ & $0.38 \pm 0.06$ & $0.38 \pm 0.06$ \\
\hline Final $^{* !, 2}$ & $11.1 \pm 2.6^{6}$ & $13.0 \pm 3.8^{4}$ & $11.1 \pm 2.8^{\circ}$ & $10.3 \pm 2.8^{n}$ & $10.1 \pm 2.5^{\mathrm{h}}$ \\
\hline Weight gain (\%) & 2820 & 3320 & 2820 & 2610 & 2560 \\
\hline Feed efficiency $(\%)^{*}$ & 128 & 142 & 134 & 126 & 106 \\
\hline Condition factor $* 2,+$ & $1.63 \pm 0.10^{+}$ & $1.73 \pm 0.10^{\circ}$ & $1.65 \pm 0.07^{\mathrm{b}}$ & $1,53+0.10$ & $1.66 \pm 0.12$ \\
\hline Survival rate $(\%)$ & 85.7 & 82.9 & 94.3 & 97.1 & 82.9 \\
\hline
\end{tabular}

*1 Calculated from all the fish of each tarks.

* Values (mean $\pm S D)$ in the same raw with different lcttcrs are significantly different $(P<0.05)$.

*: $100 \times$ wet weight gain/dry feed intake.

*+ Body wcight $(\mathrm{g}) \times 100 /$ (total length in $\mathrm{cm})^{3},(\mathrm{n}=15)$.

Table 4. Ash, lipid and mineral cortents in the bone of Japanese flounder fod the experimental diets*

\begin{tabular}{lccccc}
\hline Diet no. & 1 & 2 & 3 & 4 & 5 \\
\hline Ca from Ca-lactate (\%) & 0 & 0.25 & 0 & 0.25 & 0 \\
Ca from TCP (\%) & 0 & 0 & 2.5 & 2.5 & 2.5 \\
Zn (mg/kg) & 30 & 30 & 30 & 30 & 80 \\
\hline Crude ash (\%) & 65.2 & 67.2 & 68.3 & 67.6 & 68.0 \\
Crude lipid (\%) & 2.40 & 2.29 & 2.20 & 2.16 & 2.34 \\
Ca (\%) & 26.5 & 26.5 & 26.7 & 25.7 & 25.4 \\
P (\%) & 11.8 & 11.4 & 12.0 & 11.5 & 11.5 \\
Mg (\%) & 0.51 & 0.46 & 0.49 & 0.48 & 0.52 \\
K ( $\mu \mathrm{g} / \mathrm{g})$ & 264 & 258 & 248 & 260 & 254 \\
Fe $(\mu \mathrm{g} / \mathrm{g})$ & 280 & 292 & 270 & 275 & 282 \\
$\mathrm{Zn}(\mu \mathrm{g} / \mathrm{g})$ & 242 & 253 & 170 & 150 & 239 \\
$\mathrm{Mn}(\mu \mathrm{g} / \mathrm{g})$ & 139 & 138 & 128 & 118 & 121 \\
$\mathrm{Cu}(\mu \mathrm{g} / \mathrm{g})$ & 7.6 & 7.5 & 7.2 & 6.8 & 7.1 \\
\hline
\end{tabular}

* Dry matter basis. Analytical values of composite sample of bone from all the fish of each tank. 
easily digestible $\mathrm{Ca}$ and $\mathrm{Zn}$ to the diet might be suitable to improve the growth and mineral contents of bone. As TCP decreased the availability of Mn, a supplementation of Mn to TCP-riched diet also should be considered.

\section{ACKNOWLEDGEMENTS}

The authors wish to express gratitude to Drs. Sciichi Matsui and Takao Yoshimatsu for their helps in conducting this research. Thanks are due to the staffs of Fukuoka Prefectural High School of Fisheries and Fukuoka Mariculture Corporation for kindly providing the experimental fish and the rearing facilities, respectively.

\section{REFERENCES}

Gallin, D. M., II and H. F. Phillips 1989 Dielary calcium, phytate and zinte interactions in charnel catfish. Aquacultare, 79: 259-266

Gatlin, D. M., II and R. P. Wilson 1984 Zine supplementation of practical channel catfish diets. Aquaculture, 41: $31 \cdots 36$

Halver, J. E. 1957 Nutrition of salmonid fishes. III. Water--soluble vitamin requirements of chinook sälinon. J. Nutr., 62: 225-243

Hardy, R. W. and K. D. Shearer 1985 Effect of dictary calcium phosphate and zine supplementation on whole body zinc concentration of rainbow trout (Salmo gatrineri). Cam. J. Fish. Aquat. Sci., 42: 181-184

Hossain, M. A. and M. Furuichi 1998 Availability of environmental and dietary calcium in liger puffer. Aquacult. Int., 6: 121-132

IIossain, M. A. and M. Furuichi 1999 Effect of delelion of calcium supplement from purified diet on growth and bone mineralization in red sea bream. If Fac. Agr, Kyushu Iniv., 44: 91-97

Hossair, M. A. and M. Furuichi 2000a Essentiality of calcium supplement to the diet of Japanese flounder. Fisheries Sci, (in press).

Hossain, M. A. and M. Furuichi 2000b Effects of dictary tricaleium phosphate on the growth, feed cfliciency and mineralization of bone in young red sea bream. J. Fac. Agr, Kyushu Lniw., 44: $265-271$

Richardson, N. L., D. A. Higgs, R. M. Beames and J. R Mcbride 1985 Influence of dietary calcium, phosphorus, zinc and sodium phytate level on cataract incidence, growth and histopathology in juvenile chirook salmon (Oncorhynchus tshawytscha). J. Nutr., 115: 55:3-567

Satoh, S., T. Takeuthi and T. Watanabe 1987a Availability to rainbow trout of zinc in white fish meal and of various zinc compounds. Nippon Suisan Gakkaishi, 53: 595-5999

Satoh, S., K. Tabata, K. Izume, T. Takeuchi and T. Watanabe $1987 \mathrm{~b}$ Effect of dietary tricalcium phosphate on availability of zine to rainbow trout. Nippon Susan Gakkaishi, 53: 1199-1205

Takaoka, O., K. Takii, M. Nakamura, H. Kumai and M. Takeda 1995 Identification of the feeding stimulants for tiger puffer. Fisheries Sci., 61: 8333-836 